\title{
Documentation of tribal's traditional knowledge of medicinal plants from Renlagadda Thanda, Kodangal mandal, Mahabubnagar Dist, Telangana, India
}

\author{
Shivakumar Singh ${ }^{1 *}$, Rajender Singh $^{2}$ \\ ${ }^{1}$ Department of PG Studies and Research in Botany, MVS Govt. Degree and PG College, \\ Mahabubnagar, Telangana, India. \\ ${ }^{2}$ Department of Studies and Research in Botany, SV Arts and science, Degree and PG College, \\ Palem, Mahabubnagar, District, Telangana, India. \\ *E-mail address: shivakumarsinghp@gmail.com
}

\begin{abstract}
The aim of this report is giving the importance in need of ground leveal documentation of medicinal plants, their ingrediants and usage. To be effort has been made to evaluate plants used for medicare by the tribal people of Renla Gadda Thanda, Kodangal mandal, Mahabubnagar Dist, Telangana. Due to be deficient in of modern healthcare facilities and poor economic conditions, the tribal people of the Thanda fully depend on in the vicinity available medicinal plants for their healthcare needs. In the present report a total of 24 ethnomedicinal plants from 23 genus and 24 species occupied 18 families were recorded. The thorough information i.e., Usage, to be treated disorder, Parts used recorded. This is a first report from the Renlagadda Thanda of Kodangal mandal. The study area having wealthy in medicinal plants flora and tribal communities with latest usages. Documentation of traditional knowledge on medicinal plants from the village or thanda level is the elementary and necessary samples for novel medication.
\end{abstract}

Keywords: Tradition medicinal plants; Tribal community; Renlagadda Thanda; Kodangal; Mahabubnagar; Telangana

\section{INTRODUCTION}

The tribal medicinal system extremely deep rooted in Indian culture. The usage of plants in India is very difficult to separate from there culture. Herbs are using not only for curing diseases but also during several ceremony, they belive green should gives victory. Today, there is growing ambition to unravel the role of traditional medicinal plants studies in trapping the centuries elder conventional folk knowledge as well as in searching new plants resources of food, drugs, shalter etc (S.K. Jain 1987). Among the natural resources the traditional knowledge on medicinal plants is considered as important sources of medicine, the diversity of medicinal plants and their rich therapeutic wisdom in Renlagadda thanda, made us to think over the utility of this natures gift for the benefit of society. Since early times, man has used plants for medicine, fuel, timber and food. The ethnic knowledge on the use of plants as medicine is well documented (Anonymous 1994, J.K. Maheswari 2000, R.N. Chopra et al., 
1956). Indigenous remedies have originated directly or indirectly from folklore's rituals and superstitions (Mitra Roma 1989). The interest in ethno botanical research has increased considerably for the last couple of decades. Many scholars directed towards the valorization of ethnobotanical patrimony because of the belief that such remedies may be useful sources for new therapeutic products (F. Lentini 2000, H.K. Sharma 2001).

To day there is in need to document and report at village or thanda like basic level. Usually all most all reports choosing huge areas but they were not coverd all the selected area, if once they coverd it may some missings also happened. So the keeping aim of this object the present documentation desined and completed. About $90 \%$ of the people of Renlagadda thanda have depending on traditional medicinal plants as it is commonly available and does not have any side effects at the optimum level. Since, no such detailed studies reported so far from Renlagadda Thanda of Mahabubnagar Dist, Telangana, so these documented results here reporting.

\section{MATERIALS AND METHODS}

The documentation of tradtional knowledge on medicinal plants from Renlagadda Thana was conducted during June 2014- Dec 2014. In this period the frequent visitings was made to study area on the basis of tribals interview the collection, identification and authentication of the medicinal plants with their therapeutic properties against various ailments was recorded. The farm families used the questionnaire based survey along with informal discussions to gather information regarding the use of medicinal plants for various ailments at home scale level single people in each or in two homes who are the expert or practitioners, were interviewed. These plants species were deposited in the Department of Botany, MVS Govt UG \& PG college, Mahabubnagar (J.S. Gamble et al., 1957, Y.N. Seetharam et al., 2000). Plant species used for diverse health problems, together with the local names, part used, method of preparation, form and the mode of utilization were recorded and compiled. This was done with the help of young key informants, Thanda elders and local healers Thanda elders are the major key players, in the traditional health care system. They have always played a critical role in maintaining the health of the aboriginal people(L.A. Colomeda et al., 2000). They are living reserviors and depositories of the oral traditions for ceremonies, songs to sing for gathering the plants and medicines to use that will care their people (V.L. Kuletz et al., 1998, J.B. Alcorn 1981A, J.B. Alcorn 1981B).

\section{STUDY AREA}

The study area Renlagadda Thanda located in Juntupally forest. Its near to Kodangal Mandal, Mahabubnagar district, Telangana State, India (Fig.1). It is also located near boarder of Sedam taluk, Karnataka state. This Thanda located in the midpoint of the forest. There is no sufficient way for transportation till the day. The people of the study area were finacially very much backward, more than $80 \%$ of the thanda people were illitrates. They can speak three languages Lambadi, Telugu, Hindi. The plant assortment is very rich because this area located in heart point of Juntipally forest and a excellent amount of medicinal plants are available. 


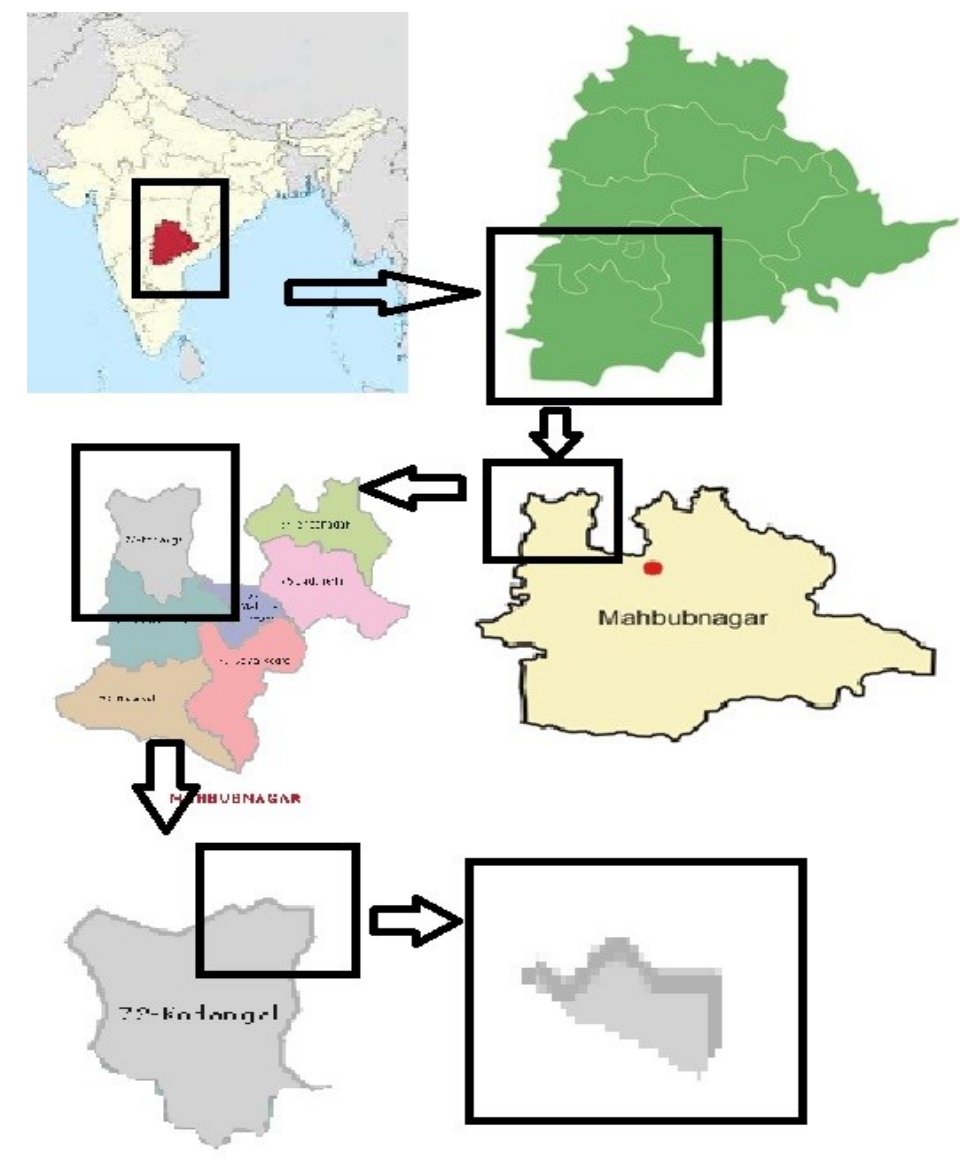

Figure 1: Study area Renla Gadda Thanda, Kodangal Mandal, Mahabubnagar District, Telangana State, India.

\section{RESULTS AND DISCUSSION}

The study area (Figure 1) comprises huge forest and small reservoir i.e., Juntupally. So the Thanda not having conviniant transportation till the day. In the event of documentation a total of 24 ethnomedicinal plants from 23 genus and 24 species occupied 18 families were recorded. Solanaceae represented 03, followed by Euphorbiaceae and Asclipidiaceae represented each two, the remaing 15 families reprented single species each (Figire 4). The thorough information i.e., family, scientific name, local names, part used, usage and to be treated disorder were arranged in chronological order (Table 1).

This is a first report from the Renlagadda Thanda of Kodangal mandal. The study area having wealthy in medicinal plants flora and tribal communities with latest usages. A total number of 14 tribal practiceners of ( 09 men, 05 women)were interviewed whose age ranged from 35-90 years.. A common 33 different diseases like snake bite, bone fracture, asthama, cough, fever, jaundes, ruhmantic pains etc., were frequently treated by the 14 tribal practiceners. Documentation of traditional knowledge on medicinal plants from the village or thanda level is the elementary and necessary samples for novel medication.

In details discussion and data interpretation was done by various paprameters like frequency distribution of sources, Percentage distribution of growth forms, family wise distribution and percentage, distribution of habitat forms, ailmants treatment pacentage 
distributions. From initial period people have prepared usage of plants for their basic needs, sustenance, medicare and livelihood. Some plants used by people are cultivated, while others grow in wild conditions. Useally the tribes depend principally on plants, for food, clothing, housing, medicine, oil, agriculture implements, art, crafts and coloring and a host of other requirements (J. Maheshwari 1995).

The aim of this report is giving the importance in need of ground leveal documentation of medicinal plants, their ingrediants and usage. To be effort has been made to evaluate plants used for medicare by the tribal people of Renla Gadda Thanda, Kodangal mandal, Mahabubnagar Dist, Telangana. Due to be deficient in of modern healthcare facilities and poor economic conditions, the tribal people of the Thanda fully depend on in the vicinity available medicinal plants for their healthcare needs.

Table 1. Tradtional knowledge on medicinal plants of Renlagadda Thanda, Kodangal mandal, Mahabubnagar district, Telangana, India.

\begin{tabular}{|c|c|c|c|c|}
\hline Family & $\begin{array}{l}\text { Scientific } \\
\text { Names \& } \\
\text { local names }\end{array}$ & $\begin{array}{l}\text { Part } \\
\text { used }\end{array}$ & $\begin{array}{l}\text { Mode of preparation \& } \\
\text { method of usage }\end{array}$ & Ailment \\
\hline Fabaceae & $\begin{array}{c}\text { Abrus } \\
\text { precatorius } \\
\text { Linn. } \\
\text { Guruginja } \\
\text { theega }\end{array}$ & Seed & $\begin{array}{l}\text { Dried seeds after roasted with } \\
\text { chilly eaten }\end{array}$ & $\begin{array}{c}\text { Sexual } \\
\text { stimulant }\end{array}$ \\
\hline \multirow[t]{2}{*}{ Liliaceae } & $\begin{array}{l}\text { Aloe vera }(\mathrm{L}) \\
\text { N.Burm. }\end{array}$ & \multirow[t]{2}{*}{ Leaf } & $\begin{array}{c}\text { Leaf paste along with } \\
\text { Turmeric powder is taken } \\
\text { internally once a day for } 3 \\
\text { days. }\end{array}$ & Chest pain \\
\hline & $\begin{array}{l}\text { Kalabanda } \\
\text { chettu }\end{array}$ & & $\begin{array}{c}\text { Leaf paste with sugar is taken } \\
\text { internally thrice a day for } 2 \\
\text { days. }\end{array}$ & Body heat \\
\hline \multirow[t]{3}{*}{ Papaveraceae } & $\begin{array}{l}\text { Argemone } \\
\text { mexicana } \\
\text { Linn. }\end{array}$ & \multirow[t]{3}{*}{ Seed } & $\begin{array}{l}\text { Powdered applied inserted into } \\
\text { the fish and prayed taken } \\
\text { empty stomach. }\end{array}$ & Asthma \\
\hline & $\begin{array}{l}\text { Jeeripothu } \\
\text { Alaamu }\end{array}$ & & $\begin{array}{c}\text { Powder and turmeric applied } \\
\text { on infected skin. }\end{array}$ & $\begin{array}{l}\text { Skin disease } \\
\text { Leprosy }\end{array}$ \\
\hline & & & $\begin{array}{l}\text { A powder used as a tooth } \\
\text { powder. }\end{array}$ & Dental caries \\
\hline \multirow[t]{2}{*}{ Meliaceae } & $\begin{array}{l}\text { Azadirachta } \\
\text { indica } \\
\text { A.juss. }\end{array}$ & \multirow[t]{2}{*}{ Leaf } & $\begin{array}{l}\text { Dry leaves burnt with dried } \\
\text { Toulouse leaves at night in } \\
\text { the room. }\end{array}$ & $\begin{array}{l}\text { Mosquito's, } \\
\text { skin diseases }\end{array}$ \\
\hline & Vepa chettu & & $\begin{array}{l}\text { Twig made brushes used daily } \\
\text { morning. }\end{array}$ & $\begin{array}{l}\text { Bleeding } \\
\text { gums Mouth } \\
\text { ulcers }\end{array}$ \\
\hline Asclepiadaceae & $\begin{array}{l}\text { Calotropis } \\
\text { gigantea }\end{array}$ & Leaf & $\begin{array}{l}\text { Leaf crushed with neem leaf } \\
\text { mixed in honey administered }\end{array}$ & $\begin{array}{l}\text { Sevier burn } \\
\text { Injury, }\end{array}$ \\
\hline
\end{tabular}




\begin{tabular}{|c|c|c|c|c|}
\hline & Linn. & & on part till cure. & swelling \\
\hline & Jilledu chettu & & $\begin{array}{l}\text { Leaves warmed, over fire } \\
\text { applied on chest }\end{array}$ & $\begin{array}{l}\text { Rheumatic } \\
\text { pain }\end{array}$ \\
\hline Caricaceae & $\begin{array}{l}\text { Carica } \\
\text { papaya Linn. } \\
\text { Popaya } \\
\text { chettu }\end{array}$ & Leaf & $\begin{array}{l}\text { Leaf paste with sugarcane } \\
\text { juice and neem leaf paste } \\
\text { mixed administered orally at } \\
\text { early morning for } 15 \text { days. }\end{array}$ & $\begin{array}{l}\text { Sevier } \\
\text { jaundice }\end{array}$ \\
\hline Asteraceae & $\begin{array}{l}\text { Carthamus } \\
\text { tinctorius } \\
\text { Linn. }\end{array}$ & Flower & $\begin{array}{l}\text { Flower Juice, sugar, turmeric } \\
\text { mixed in half glass water } \\
\text { administered once a day for } 1 \\
\text { week. }\end{array}$ & Fever \\
\hline & $\begin{array}{c}\text { Tella } \\
\text { Kusuma. }\end{array}$ & & $\begin{array}{l}\text { Flower paste applied to } \\
\text { infected part } 2 \text { times a day for } \\
6 \text { days. }\end{array}$ & Skin disease \\
\hline \multirow[t]{3}{*}{ Caesalpinicaeae } & $\begin{array}{l}\text { Cassia tora } \\
\text { Linn. }\end{array}$ & Root & $\begin{array}{l}\text { Ox horn powder, root paste } \\
\text { mixed in half glass water, } \\
\text { administered orally twice daily } \\
\text { for } 35 \text { days. }\end{array}$ & $\begin{array}{l}\text { Bone fever, } \\
\text { Dum \& Duff }\end{array}$ \\
\hline & $\begin{array}{l}\text { Advi } \\
\text { thangedu }\end{array}$ & Seed & $\begin{array}{c}\text { Seed paste, curd given daily } 2 \\
\text { spoonful after meals for } 2 \\
\text { days. }\end{array}$ & Ring worm \\
\hline & & \multirow{3}{*}{ Leaf } & $\begin{array}{c}\text { Seed powder mixed in tea } \\
\text { given 2-3 times daily for } 2 \\
\text { days. }\end{array}$ & $\begin{array}{l}\text { Cough, } \\
\text { Headache }\end{array}$ \\
\hline Apiaceae & $\begin{array}{l}\text { Coriandrum } \\
\text { sativum L. }\end{array}$ & & $\begin{array}{l}\text { Teaspoonful of fresh juice of } \\
\text { leaves taken every night with } \\
\text { honey. }\end{array}$ & $\begin{array}{c}\text { Vitamin } \\
\text { Deficiency }\end{array}$ \\
\hline (Umbelliferae), & Kothimera & & $\begin{array}{l}\text { Leaf juice } 1-2 \text { teaspoon mixed } \\
\text { with a glass of fresh } \\
\text { buttermilk is given } 2-3 \text { times } \\
\text { daily. }\end{array}$ & Indigestion \\
\hline Solanaceae & $\begin{array}{l}\text { Datura } \\
\text { stramonium } \\
\text { Linn. } \\
\text { Ummentha }\end{array}$ & Flower & $\begin{array}{l}\text { Flower and root paste with } \\
\text { Adansonia digitata L. Leaf } \\
\text { paste applied on fractured part } \\
\text { covered with ties bamboo } \\
\text { sticks around it with human } \\
\text { hairs twice in } 1 \text { month till it } \\
\text { cures. }\end{array}$ & Bone fracture \\
\hline Euphorbiaceae & $\begin{array}{l}\text { Emblica } \\
\text { officinalis } \\
\text { Usiri }\end{array}$ & Fruit & $\begin{array}{l}\text { Fruit mashed, filtered, mixed } \\
\text { with glycerin and } \\
\text { administered, twice daily for } \\
\text { one week. }\end{array}$ & $\begin{array}{c}\text { Eye } \\
\text { infections }\end{array}$ \\
\hline
\end{tabular}




\begin{tabular}{|c|c|c|c|c|}
\hline \multirow[t]{2}{*}{ Lythraceae } & $\begin{array}{l}\text { Lawsonia } \\
\text { inermis L. }\end{array}$ & \multirow[t]{2}{*}{ Leaf } & $\begin{array}{l}\text { Leaf and Nilgiri oil mixed } \\
\text { applied on four heads for } 30 \\
\text { minutes for once a week. }\end{array}$ & $\begin{array}{l}\text { Migraine } \\
\text { Headache }\end{array}$ \\
\hline & $\begin{array}{l}\text { Mydaaku } \\
\text { chettu }\end{array}$ & & $\begin{array}{l}\text { Leaf paste used in dying, } \\
\text { coloring and decorations in } \\
\text { various ceremonies. }\end{array}$ & Coloring \\
\hline \multirow[t]{2}{*}{ Santalaceae } & $\begin{array}{l}\text { Ocimum } \\
\text { santum L. }\end{array}$ & \multirow[t]{2}{*}{$\begin{array}{l}\text { Whole } \\
\text { plant }\end{array}$} & $\begin{array}{l}\text { Leaves are eaten raw to treat } \\
\text { fever and for Weakness for } \\
\text { trice a day. }\end{array}$ & \multirow[t]{2}{*}{ Weakness } \\
\hline & Thulasi & & & \\
\hline \multirow[t]{2}{*}{ Apocynaceae } & $\begin{array}{l}\text { Rauwolfia } \\
\text { serpentine } \\
\text { (L) Benth. }\end{array}$ & \multirow[t]{2}{*}{ Root } & $\begin{array}{l}\text { Root decoction administered } \\
\text { early morning once a day for } 1 \\
\text { month. }\end{array}$ & $\begin{array}{l}\text { Nervous } \\
\text { disorders }\end{array}$ \\
\hline & Sarpagandha & & $\begin{array}{l}\text { Root decoction given orally } \\
\text { once avoid sleep for } 1 \text { night. }\end{array}$ & Snake bite \\
\hline \multirow[t]{2}{*}{ Euphorbiaceae } & $\begin{array}{l}\text { Ricinus } \\
\text { communis }\end{array}$ & \multirow[t]{2}{*}{ Seed } & $\begin{array}{l}\text { Seed oil messaged to children, } \\
\text { Old age person daily morning } \\
\text { before bath. }\end{array}$ & \multirow[t]{2}{*}{$\begin{array}{l}\text { Strengthen } \\
\text { the bone }\end{array}$} \\
\hline & Aamudamu & & & \\
\hline \multirow[t]{2}{*}{ Malvaceae } & $\begin{array}{l}\text { Sida acuta } \\
\text { Burm. }\end{array}$ & \multirow[t]{2}{*}{ Leaf } & $\begin{array}{c}\text { Leaf paste and shoots } \\
\text { powdered mixed with coconut } \\
\text { oil administered } 2 \text { times for } 2 \\
\text { weeks. }\end{array}$ & $\begin{array}{l}\text { Boil skin } \\
\text { diseases }\end{array}$ \\
\hline & Nagabala & & $\begin{array}{l}\text { Root paste directly applied } \\
\text { with Tridex procumbens leaf } \\
\text { paste for } 2 \text { times a day for } 5 \\
\text { days. }\end{array}$ & $\begin{array}{l}\text { Severe } \\
\text { wounds }\end{array}$ \\
\hline \multirow[t]{2}{*}{ Solanaceae } & $\begin{array}{l}\text { Solanum } \\
\text { melangena } \\
\text { L. }\end{array}$ & \multirow[t]{2}{*}{ Fruit } & $\begin{array}{c}\text { Fruit pieces of fruit are soaked } \\
\text { in water for } 30 \mathrm{~min} \text {. and wash } \\
\text { the hands before sleeping. }\end{array}$ & \multirow[t]{2}{*}{ Perspiration } \\
\hline & Vankaaya & & & \\
\hline \multirow[t]{3}{*}{ Combretaceae } & $\begin{array}{l}\text { Terminalia } \\
\text { arjuna }\end{array}$ & Leaf & $\begin{array}{c}\text { Leaf juice } 2 \text { to } 3 \text { drop twice } \\
\text { day. }\end{array}$ & Eye infection \\
\hline & Tella maddi & \multirow[t]{2}{*}{ Fruit } & $\begin{array}{c}\text { Fruit pulp salt long pepper and } \\
\text { honey mixed given without } \\
\text { water. }\end{array}$ & Cough \\
\hline & & & $\begin{array}{c}\text { Fruit fried covered with jowar } \\
\text { flour fried with salt and } \\
\text { administered once daily } \\
\text { morning. }\end{array}$ & Catarrh \\
\hline
\end{tabular}




\begin{tabular}{|c|c|c|c|c|}
\hline Menispermaceae, & $\begin{array}{c}\text { Tinospora } \\
\text { cordifolia } \\
\text { (Willd) } \\
\text { Miers. } \\
\text { Thippatheega }\end{array}$ & Leaf & $\begin{array}{l}2 \text { spoon leaf powder } 2 \mathrm{gm} \\
\text { emblica officinalis fruit } \\
\text { powder mix with honey } \\
\text { administered for } 1 \text { month. } \\
\text { Powder, pulp of pomegranate } \\
\text { made decoction Consumed } \\
\text { once a day for } 2 \text { weeks. }\end{array}$ & Hair fall \\
\hline Asclepiadaceae & $\begin{array}{l}\text { Tylophora } \\
\text { asthmatica } \\
\text { (Burm.f) } \\
\text { Merr. } \\
\text { Meka } \\
\text { meyani aaku }\end{array}$ & Root & $\begin{array}{l}\text { Pepper leaf powder is mixed } \\
\text { with honey. }\end{array}$ & Malaria \\
\hline Verbenaceae & $\begin{array}{c}\text { Vitex } \\
\text { nigundo L. } \\
\text { Vaayili }\end{array}$ & Twig & $\begin{array}{l}\text { Use of soft twig as toothbrush } \\
\text { for bad breath. } \\
\text { Hot fomented leaf Along with } \\
\text { salt in a muslin cloth is placed } \\
\text { on affected region. }\end{array}$ & $\begin{array}{l}\text { Healthy } \\
\text { Arthritis }\end{array}$ \\
\hline Solanaceae & $\begin{array}{l}\text { Withania } \\
\text { somnifera L, } \\
\text { Dunal. } \\
\text { Ashvagandha } \\
\text {, }\end{array}$ & Leaf & $\begin{array}{c}\text { Leaf paste mixed in vanaspati } \\
\text { mixed nicely and applied on } \\
\text { wounds once a day for week. } \\
\text { Root leaf paste mixed in } \\
\text { turmeric }\end{array}$ & $\begin{array}{c}\text { Bedsores } \\
\text { Wounds } \\
\text { Ulcers }\end{array}$ \\
\hline
\end{tabular}

The data was constrate with the existing literature in different regions of Telangana and India on medicinal plants (K.R. Kirtikar \& B.D. Basu 1935, V.S. Agarwal 1986, G. Watt 1972, S.J. Ali et al., 1989, R.N. Chopra et al., 1969) and many plant formula listed are not recorded earlier (M. Sala Uddin et al., 2015, W. Gritsanapan 2010). In some neighbor states of India (I. K. Sundaram 1998, S.N. Yoganarasimhan et al., 1991, M.J. Bhandari et al., 1995, V.H. Harsha et al., 2003). Nevertheless, in Renlagadda thanda, no study on documentation of tradtional medicinal have been carried out. This is a foremost and exclusive report from the study area. The recipe and consistency of these efficient phytomedicine should be confident for their sustainable uses. The data accrued is expected to serve as a basic source for the growth of herbal drug industries to recover tribal and rural wealth.

The traditional medicinal healers from the reported region, frequently the plants are used either single or in combination. In the present documentation the different parts of the plants were used with numerous variation in the technique of preparation when compared with prvious reports of M. Sala Uddin et al., (2015), Wandee Gritsanapan (2010).

Frequency in distribution sources, Percentage in distribution of growth forms, distribution of ethno-medicinal plants into taxonomic groups, Frequency in distribution of plant parts of ethno-medicinal plants against various ailments was analyzed. 


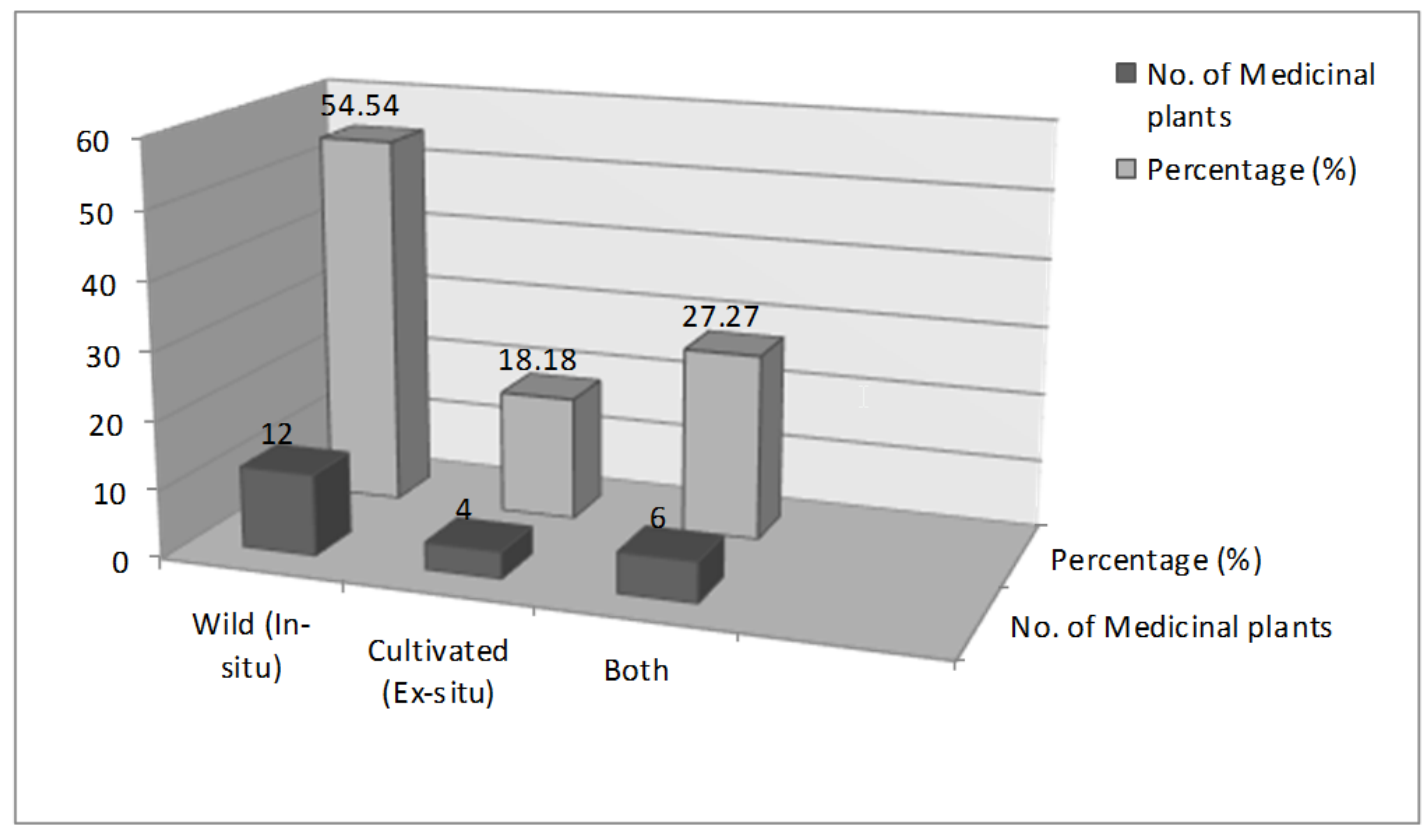

Fig. 2. Frequency distribution of sources of Tribal-medicinal plants in the study area.

Frequency distribution sources of medicinal plants in the study area shown in fig.2. Of 22 plants species documented, shows that the Wild share the largest proportion with 12 species $(54.54 \%)$ followed by Cultivated $4(18.18 \%)$ and both (In-situ \& ex situ) each with 06 species $(27.27 \%)$.

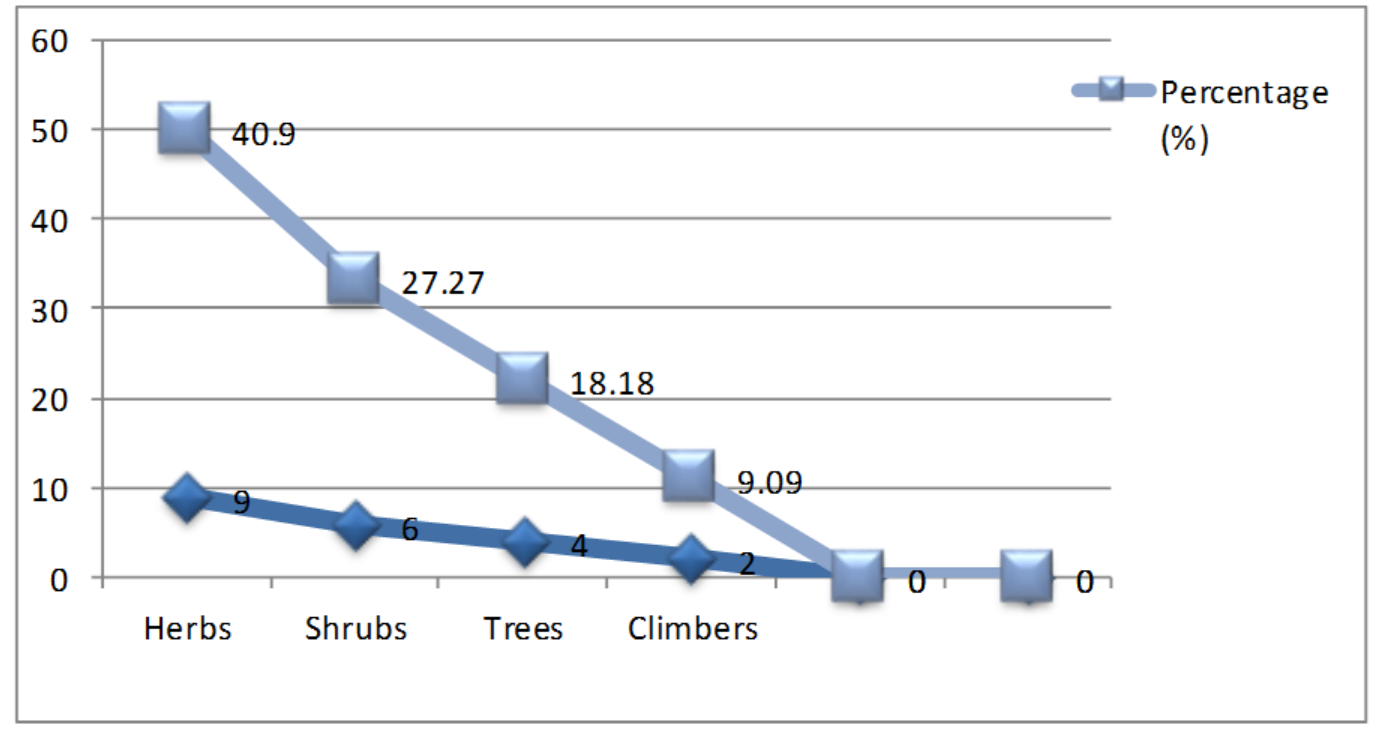

Fig. 3. Percentage distribution of growth forms of Tribal-medicinal plants.

The analysis of habits (Fig. 3) of plants documented, shows that herbs share the largest proportion with 09 species $(40.9 \%)$ followed by shrubs with 06 species $(27.27 \%)$, Trees with 04 species (18.18\%) and climbers with 2 species $(09.09 \%)$. 


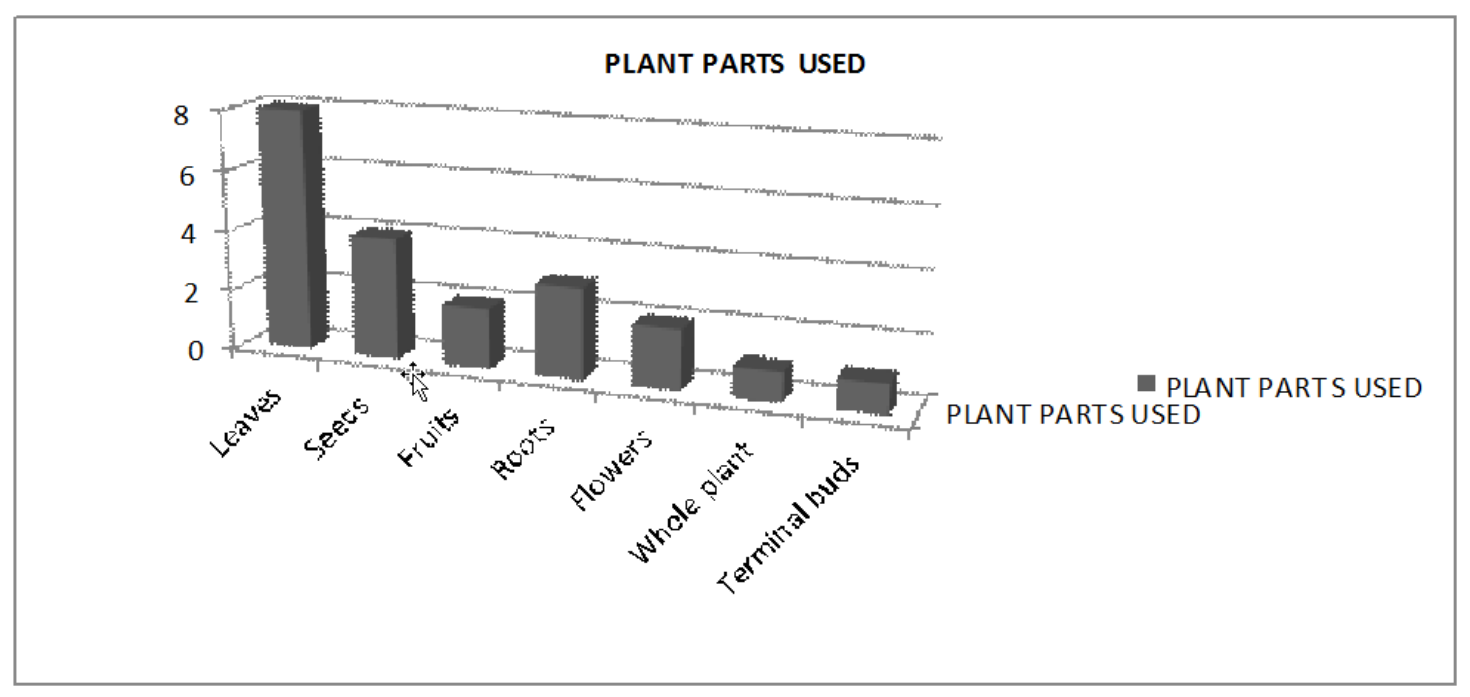

Fig. 4. Plant parts used in Renla Gadda Thanda for traditional treatments.

In the part of documentation 07 types of parts is being used treating in various ailments. The number and parecentage given in figure 7 .

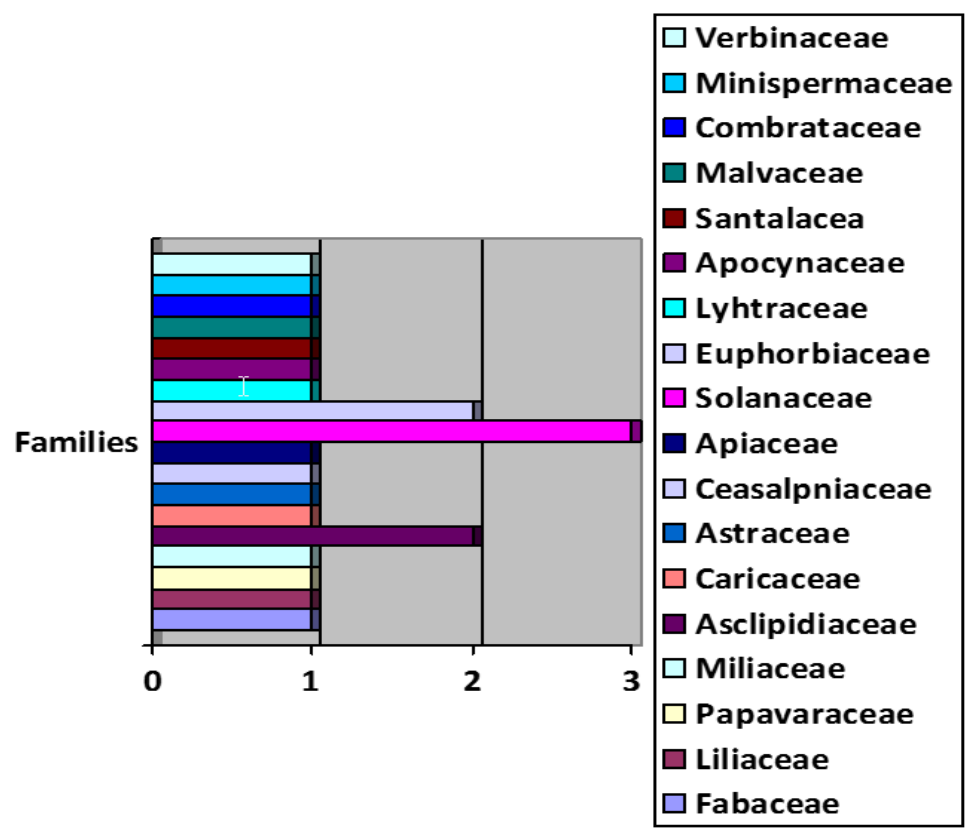

Fig. 4. Tribal-medicinal plants distribution family wise.

The documented results was analysed families wise, where the total 18 families recorded. The dominated families like Solanaceae followed by Euphorbiaceae and Asclipidiaceae. While the remaing 15 families representing single species of each (Figure 4). 


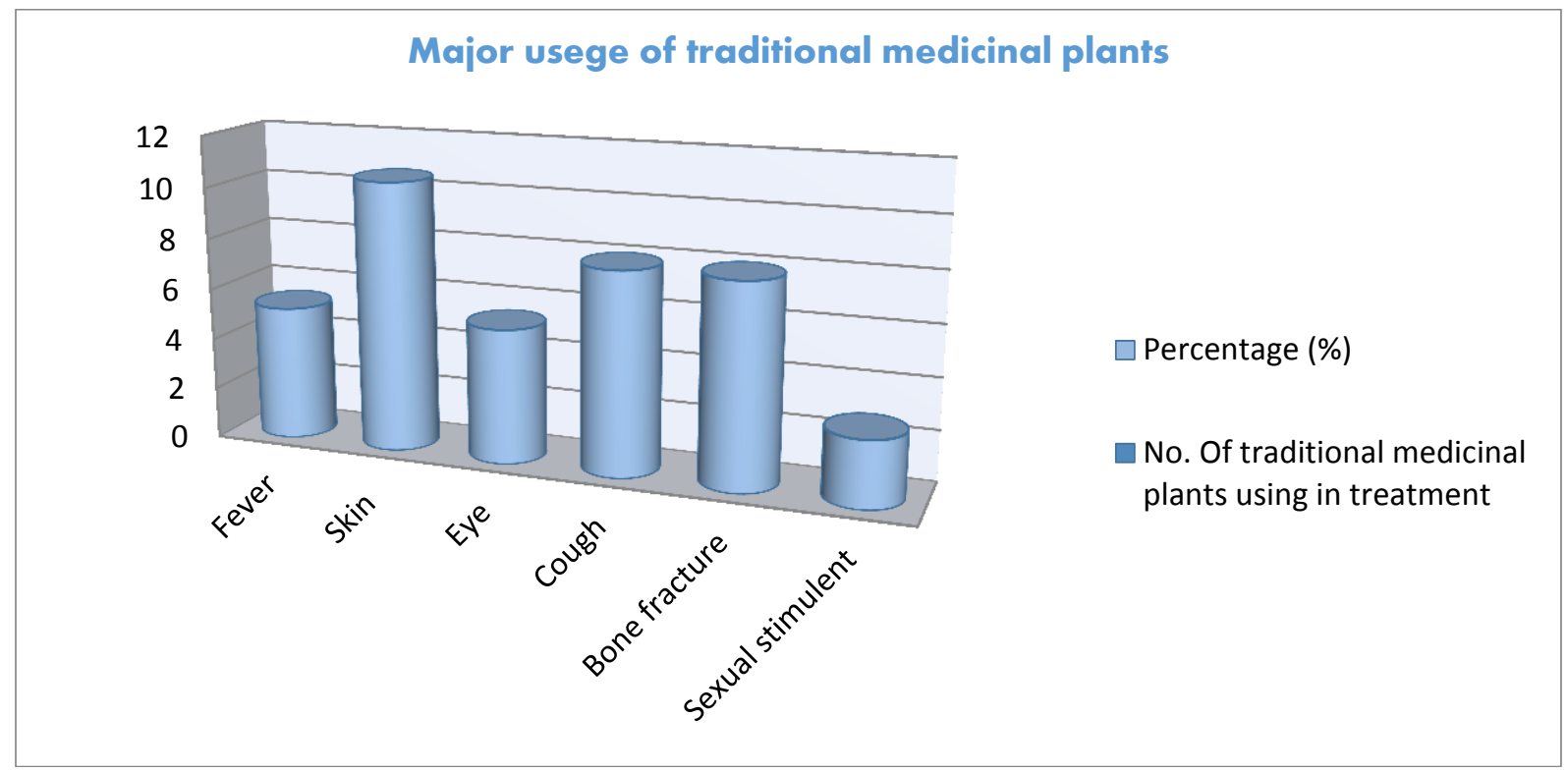

Fig. 6. Tribal medicinal plants used in Renla Gadda Thanda for various disorders treatments.

The distribution of 22 medicinal plants curing 33 ailments. Majorly with $10.52 \%$ of plants using against skin ailments followed by $7.89 \%$ bone fracture, cough, $5.26 \%$ against eye disorders, fever. While the 28 diseases treated by single tribal plants.

\section{CONCLUSION}

The present report successfully completed ground level documentation of selected small study area. This is the basic report from the Renlagadda thanda, here the formulation usage knowledge utmost newly reported. This will be foundation for auxiliary phytochemical, pharmacological studies and in drug design.

\section{Acknowledgement}

Authors are grateful to the healers and youth of Renlagadda thanda, who were co-operated and shared their secret information of traditional medicine.

\section{References}

[1] S.K. Jain, A Manual of Ethnobot, Scientific Publication, Jodhpur, India (1987).

[2] Anonymous, Ethnobotany in India-A status report, Ministry of environment and Forests, Govt of India, (1994).

[3] J.K. Maheswari, Ethnobotany and Medicinal plants of Indian subcontinent, (Scientific Publisher, Jodhpur), (2000), 672. 
[4] R.N. Chopra, S.L. Nayer, I.C. Chopra, Glossary of Indian Medicinal Plants, Council of Scientific and Industrial Research, New Delhi, (1956).

[5] Mitra Roma, Therapeutic terms used in Medico Botany, in: Method and Approaches in Ethnobotany, by SK Jain,Society of Ethno botanists, Lucknow, (1989) 79.

[6] F. Lentini, The role of Ethnobotanics in Scientific research. State of Ethnobotanical knowledge in Sicily, Fitoterapia 71 (2000) 583-588.

[7] H.K. Sharma, L. Changte, A.K. Dolui, Traditional medicinal plants in Mizoram, India, Fitoterapia 72 (2001) 146.

[8] J.S. Gamble, C.E.C. Fisher, Flora of the Presidency of Madras, Reprint, Vol I-III, Botanical Survey of India, Calcutta (1957).

[9] Y.N. Seetharam, K. Kotresh, S.B. Uplaonkar, Flora of Gulbarga district, Gulbarga University, Gulbarga, (2000).

[10]L.A. Colomeda, E.R. Wenzel, Medicine Keepers, Issues in Indigenous health, Critical Public Hlth 10(2) (2000) 243.

[11]V.L. Kuletz, The tainted desert, in: Environmental and Social Ruin in theAmerica West, Oxford University Press, London/New York (1998) 24.

[12]J.B. Alcorn, Haustee: Non-crop Resource Management, Human Ecol 9 (1981) A 395.

[13]J.B Alcorn, Some factors influencing botanical resource perception among the Haustee: Suggestion for ethno botanical enquiry, J Ethno biol 1 (1981) B, 221.

[14]J. Maheshwari, Current Trends and Future Perspectives in Ethno botanical Research. J Liv World 2(2) (1995)1.

[15]K.R. Kirtikar, B.D. Basu, Indian Medicinal Plants, Periodical Experts, Delhi 1- 4 (1935).

[16]V.S. Agarwal, Economic plants of India, Kailash Prakashan, Calcutta (1986).

[17]G. Watt, A Dictionary of the Economic Products of India, Periodical Experts,Delhi 14 (1972).

[18] S.J. Ali, S.N. Dixit, Folk herbal drugs of a Sub- Himalayan forest tract in eastern Uttar Pradesh, Bio J 1(1989) 13-18.

[19]R.N. Chopra, I.C. Chopra, V.S. Varma, Supplement to Glossary of Indian Medicinal Plants, Council of Scientific and Industrial Research, New Delhi (1969).

[20]M. Sala Uddin, J.J. Chakma, K.M.M. Alam, S.B. Uddin, Ethno-medico studies on the uses of plant in the Chakma community of Khagrachari district, Bangladesh, Journal of Medicinal Plants Studies 3(1) (2015) 10-15.

[21]W. Gritsanapan, Ethnomedicinal plants popularly used in Thailand as laxative drugs, Ethnomedicine: A Source of Complementary Therapeutics (2010) 295-315.

[22]I. K. Sundaram, An Ethnobotanical study of the Kodavas and other tribes of Kodagu district, Karnataka, Bull Bot Surv India 40 (1-4) (1998) 47-52.

[23] S.N. Yoganarasimhan, V.S. Togunashi, K.R. Keshavmurthy, Govindaiah, Medical Botany of Tumkur district in Karnataka India, J Econ Tax Bot 15 (1991) 391. 
[24] M.J. Bhandari, K.R. Chandrashekar, K.M. Kaveriappa, Medicinal Ethnobotany of Siddis of Uttara Kannada District in Karnataka India, J Ethnopharmocol 47 (3) (1995) 149-158.

[25] V.H. Harsha,S.S. Hebbar, V. Sripathi, G.R. Hegde, Ethnomedicobotany of Uttara Kannada district in Karnataka India, J Ethno bot 87 (2003) 37. 